\author{
Iulia BUTNARU, PhD Candidate \\ E-mail: iuliacsc@yahoo.com \\ Lecturer Laura BRAD, PhD \\ E-mail: laura.brad@fin.ase.ro \\ Professor Iulian Viorel BRASOVEANU, PhD \\ E-mail:viorel_brasoveanu@yahoo.com \\ The Bucharest University of Economic Studies
}

\title{
PROFIT SHIFTING OF EUROPEAN MULTINATIONAL COMPANIES AND CORRUPTION
}

\begin{abstract}
The decision to invest is taken based on a detailed analysis of the available options / problems that companies are facing on a certain point in time. The decision to invest abroad is driven by various factors among which are worth mentioning market size or cheap resources. The foreign investment decision is a complex process, thus a holistic understanding of the circumstances that are necessary in order to choose the best decision. In the last twenty years the presence of multinational companies in the international trade has significantly increase. The analysis conducted revealed that multinational companies are shifting their activities in jurisdictions with a low level of taxation, that are dealing with a high level of corruption, a low level of economic freedom, where the human resource is cheap, getting thus operational and tax advantages.

Keywords: profit shifting, corruption, multinational companies, economic freedom, labour cost.
\end{abstract}

\section{JEL Classification: F21, H25, H26, O15, 017}

\section{Introduction}

In the last twenty years the presence of multinational companies in the international trade has significantly increase. The understanding of the reasons that contributed to the internationalisation of their business is a key element in analysing the behaviour of a multinational company. Thus, at a certain point in time the companies may face a certain problems / identify certain opportunities that contribute to the shifting of the business across several countries. A pros and cons analysis is conducted in order to find the best decisions / solutions. In choosing the best decision, the decision maker has a clear overview over the risks that can appear by implementing the envisaged decision. Be sure, that a proper management will analyse the impact of this shift on a short and long term on the business as a whole. A permanent evaluation of the decision taken is made in order 
Iulia Butnaru, Laura Brad, Iulian Viorel Brasoveanu

to quantify the results obtained versus the resources used. Indeed, the host countries, countries where the multinational companies decide to locate their activity, are benefiting through this migration.

In fact, the access on information, technologies is spread along with the business shift. However, besides the benefits derived by the host countries as a result of the presence of the multinational companies, the tax authorities are dealing with the taxable base erosion and profit shifting. As a result, at European level / Organisation for Economic Co-operation and Development ("OECD") member states, solutions are trying to be found in order to prevent the taxable base erosion and the taxation of the profits by the jurisdiction where the value is created. Studies conducted at European / United States level reveals that indeed the obtaining of tax benefits represent an incentive for multinational companies and a key element when taking the decision to invest in a different jurisdiction. However, by implementing tax strategies it does not mean that the laws are broken. We do not talk about tax evasion (illegal evasion of taxes) we talk about tax planning. Tax planning strategies are not illegal, more specifically the corporation that have access to professional tax advisory services are benefiting from the gaps derive further to the interaction of national tax systems. We all know that the goal of a company is to derive profits. However, is a company interest to invest in a country that is dealing with corruption in order to get other benefits, maybe more important than lower taxes? The Transparency International Organisation defines the corruption as grand, petty and political, depending on the amounts of money lost and the sector where it occurs. The grand corruption is represented by those acts committed at the high level of the government officials that distort policies. Petty corruption refers to everyday abuse of power by low- and mid-level public officials in their interactions with ordinary citizens.

The effects of the corruption cannot be neglected, as corruption distorts the distribution of power, of wealth, resources and competition.

\section{Literature review}

Before taking a decision, we need to analyse the factors that conducted to such an action, more specifically does the company is facing a problem or an opportunity was identified?

A possible answer to the question why are companies engaged in international business? is the necessity to find things that are not available in the home country, such as market, cheap resources (including lower tax rates), efficiency or assets (Peter J Buckley, Pervez N Ghauri, 2015: pp. 10-21).

The effect of shifting the business between certain locations cannot be neglected. In fact, by shifting the activity between different countries the welfare of home, host, third countries and international economy is affected (Peter J Buckley, Pervez N Ghauri, 2015: pp. 10-21). 
Profit Shifting of European Multinational Companies and Corruption

A particular attention should be paid to the decisions that are made in order to obtain tax benefits. The role of the multinational companies in the last twenty years has significantly impacted the world trade. A multinational company can shift its profits through different instruments. For example, a multinational company can manipulate the transfer prices (Hines, James R, 1999: pp. 305-322; Newlon Scott, 2000:pp. 214-242, OECD, 2013 pp. 1-44), can use hybrid instruments or entities (OECD, 2013 pp. 1-44), utilize harmful tax practice (OECD, 2013 pp. 1-44) in order to reduce the taxable base.

Grubert and Mutti (1991:pp. 285-293) investigated the allocation of capital of US companies involved in manufacturing activities between thirty-three countries. In fact, Grubert and Mutti (1991:pp. 285-293) studied the relationship between the net stock of property, plant, and equipment (PPE) and the average effective tax rate. In comparison with Grubert and Mutti (1991:pp. 285-293), Hines and Rice (1994:pp. 149-182) included in their sample tax havens, as well as all affiliated companies excluding those that activate in the financial sector. Both, Grubert and Mutti (1991:pp. 285-293) and Hines and Rice (1994:pp. 149-182) concluded that the presence of multinational companies is higher in the locations with lower tax rates.

Harry Huizinga and Luc Laeven (2006:pp.1-47) investigated not only the profit shifting due to the tax differences between the jurisdiction of parent and affiliated companies, but also the impact of tax differences between the location of different host countries. The study of Harry Huizinga and Luc Laeven was performed on a European level. The conclusion of the study reveals that indeed that differences in the tax regimes among the tested countries represents an incentive for multinational companies to shift the operational activity. The conclusion of Harry Huizinga and Luc Laeven (2006:pp.1-47) is that at the European level is necessary to have a common set of rules in order to determine the taxable base. Buettner and Martin Ruf (2007: pp.151-164) concluded based on a German panel that the statutory tax rate have a significant impact in taking the decision to invest in a certain location. Clemens Fuest, Christoph Spengel, Katharina Finke, Jost H. Heckemeyer and Hannah Nusser (2013) concluded that the profit shifting effect obtained further to implementing a tax planning strategy is not violating the law. In fact, the multinational companies benefit from the gaps between the national tax systems from different jurisdictions. In order to remove the gaps at least at European level, the project regarding the Common Consolidated Corporate Tax Base ("CCCTB") should be put in place. Thus, by having a single set of rules to determine the tax base will combat the profit shifting.

All the authors mentioned above conducted their econometric models by using variables such as: different proxy for taxation (ex. effective tax rates, marginal tax rates, statutory tax rates etc.), foreign direct investments, gross domestic product, earnings before interest and tax, pre-tax profit, labour costs, 
Iulia Butnaru, Laura Brad, Iulian Viorel Brasoveanu

number of employees, fixed assets etc. As can be observed the variables used by the above mentioned authors are trying to capture the level of taxation, the market size, the cost of the resources. However, beside different variables that capture the level of taxation we want to investigate the impact of corruption on the decision of a company to invest in a certain location.

Habu, K. and Seidel, A. (version 2017) proposed a theoretical model through which large multinational companies that are involved in profit shifting activities can interact with a corrupt tax official. Their results reveal that the cost of profit shifting decreases significantly with corruption. In other words, corruption increases profit shifting that a multinational company performs. Moreover, corruption amplifies the incentives of the profit shifting activity. They also concluded that higher the corporate income tax on the home country is, larger the effect of corruption when profit shifting activities are encountered is. The effect of corruption on profit shifting is increased and is based on tax rate differences that define the savings obtained by shifting a unit of profit.

It is well known that the main goal of a company is to obtain profit. The main questions are: Does the companies break the rules in order to derive profits? or The decision to invest in a certain country is influenced by the level of corruption?

\section{Research of methodology}

\subsection{Panel data analysis}

Having in mind the hypotheses of research, we conducted our analysis that captures not only the level of taxation, but also the level of corruption. The analysis was conducted considering panel data model.

The panel data is a dataset in which the behaviour of certain elements (i.e. companies, countries etc.) could be observed both across time and cross-sectional. equation 1:

The models estimated using panel data can be written as is presented in

$$
Y_{i t}=\alpha_{i t}+\left(\gamma_{i t-\text { fixed effect }}\right)+\beta_{i t} \times X_{i t}+\varepsilon_{i t}+\left(\sigma_{i t}\right)
$$

Where

$Y$ - is the dependent variable: Number of subsidiaries;

$\alpha$-is a constant; it could have an additional term if the model is estimated using fixed effects (the additional term could be related to time, to companies or both- $\left.\left(\gamma_{\text {it-fixed effect }}\right)\right)$

$X$ - is the independent variable: Index of Corruption (CPI), Index of Economic Freedom (EFW), Labour Market (LB), CIT host, EATR host.

$\varepsilon$ is the error term. If the model is estimated considering random effects then the error term has an additional component because it is not constant, rather fluctuates over time $\left(\sigma_{i t}\right)$ 
Profit Shifting of European Multinational Companies and Corruption

In order to find the correct estimation, it is necessary to test for the relevance of fixed effect with Redundant test Effect, to test if Random effect is preferred rather than fixed effects using Hausman test and to test which model better fits the analysis between random effect and pool model considering Omitted Random test.

The analysis was conducted considering Reed's recommendation on panel estimation. There are 36 countries observations and 9 periods of time. As the number of periods is less than half of the number of countries, the method of estimation should be Period SUR effect within the generalized least square method associated with White period within the correlation matrix. Period SUR method of estimation allows for general correlation of residuals across periods for a specific cross-section (clustering by countries). Moreover, Period Sur Method corrects for heteroskedasticity and general correlation of observations within a cross-section. White period correlation matrix considers that there is a correlation cross-sectional data errors within the series and looks at cross-sectional grouping. The idea is to correct the arbitrary heteroskedasticity that can be found within cross-sectional series.

The peculiarity of the used estimator and method is related both with the Period Sur effect within the generalized least square method and with the White period within the correlation matrix. Considering the generalized least squared method, the adjusted coefficient matrix is consistent with the coefficient matrix based on the hypotheses that the mean of the error term is zero and that the unconditional variance of errors is both positive and non-singular. The importance of these arises when conducting asymptotic interference of coefficient matrix by adjusted/estimated coefficient matrix. According to (Wooldridge-pp. 148-160, we do not take into account that the estimated unconditional variance of errors is different from the initial unconditional variance of errors. In the case of the White Period correlation matrix, (Wooldrige- 2002, pp.276), the robustness is ensured in the presence of any heteroscedasticity or serial correlation when time(T) is relative small to the number of cross-sectional data $(\mathrm{N})$ - in our case the number of home host pair country. The estimations were conducted using the effects during the time period/ during 2007-2015 and does not emphasize the influence of country, of region or of geography. These effects can be observed in the case of further analysis in which the cross-sectional fixed effects included or where dummy variables for region, country or geography were defined and used into the analysis. Considering our samples' characteristics, the period fixed effect is used as it provides better results in terms of consistency and unbiased values.

The analysis was conducted using Eviews 9.0. 
Iulia Butnaru, Laura Brad, Iulian Viorel Brasoveanu

\subsection{Data sample}

In this section, we are presenting the data used and the related source in order for the reader to get a better understanding of the data behind the econometric model.

In order to investigate the phenomenon of profit shifting we firstly identified the European countries that recorded the highest / lowest level of corporate income tax rate ("CIT") during the period 2007 - 2015. Table 1 presents the European countries that recorded highest/ lowest CIT rate level during the period on which the analysis is conducted: $2007-2015$.

\section{Table 1: European countries with highest / lowest CIT rate level}

\begin{tabular}{|l|c|c|c|c|c|c|c|c|c|c|}
\hline Rank & $\mathbf{2 0 0 7}$ & $\mathbf{2 0 0 8}$ & $\mathbf{2 0 0 9}$ & $\mathbf{2 0 1 0}$ & $\mathbf{2 0 1 1}$ & $\mathbf{2 0 1 2}$ & $\mathbf{2 0 1 3}$ & $\mathbf{2 0 1 4}$ & $\mathbf{2 0 1 5}$ \\
\hline \multicolumn{8}{|c|}{ Countries with highest CIT rate (home countries) } \\
\hline $\mathbf{1}$ & DE & MT & MT & MT & MT & MT & MT & MT & MT \\
\hline $\mathbf{2}$ & IT & BE & BE & BE & BE & BE & BE & BE & BE \\
\hline $\mathbf{3}$ & MT & FR & FR & FR & FR & FR & FR & FR & FR \\
\hline $\mathbf{4}$ & BE & IT & IT & IT & IT & IT & IT & IT & IT \\
\hline $\mathbf{5}$ & FR & ES & ES & ES & ES & ES & ES & ES & DE \\
\hline $\mathbf{6}$ & ES & UK & DE & DE & DE & DE & DE & DE & LU \\
\hline \multicolumn{8}{|c|}{ Countries with lowest CIT rate (host countries) } \\
\hline $\mathbf{1}$ & RO & RO & HU & RO & RO & RO & RO & RO & RO \\
\hline $\mathbf{2}$ & LV & LV & RO & LT & LV & LV & LV & LV & LV \\
\hline $\mathbf{3}$ & LT & LT & LV & LV & LT & LT & LT & LT & LT \\
\hline $\mathbf{4}$ & IE & IE & IE & IE & IE & IE & CY & CY & CY \\
\hline $\mathbf{5}$ & CY & CY & CY & CY & CY & CY & IE & IE & IE \\
\hline $\mathbf{6}$ & BG & BG & BG & BG & BG & BG & BG & BG & BG \\
\hline
\end{tabular}

Source: Own computation of authors based on KPMG's database on corporate tax

Note: The symbols are related with two-letter country cod.

Countries with highest CIT rate (home countries):BE - Belgium, DE - Germany, ES- Spain,

FR - France, IT - Italy, LU- Luxembourg, MT - Malta and UK- United Kingdom

Countries with lowest CIT rate (host countries): BG - Bulgaria, CY-Cyprus, HU Hungary, IE- Ireland, LV- Latvia, LT- Lithuania and RO - Romania

As it can be observed in Table 1, during the analysed period Germany, Italy, Malta, Belgium, France and Spain recorded highest CIT rates, while Romania, Latvia, Lithuania, Ireland, Cyprus and Bulgaria recorded lowest CIT rates. Thus, we considered Germany, Italy, Malta, Belgium, France and Spain as being home countries and Romania, Latvia, Lithuania, Ireland, Cyprus and Bulgaria as being host countries.

For studying the impact of taxation on the decision to invest in a certain location we used the host / home statutory CIT rates and the fiscal pressure. The 
Profit Shifting of European Multinational Companies and Corruption

fiscal pressure is quantified as total tax (direct, indirect, social contributions) divided to GDP.

Table 2 presents the fiscal pressure level in each analysed country.

Table 2: Total tax (direct, indirect, social contributions) \% GDP

\begin{tabular}{|l|c|c|c|c|c|c|c|c|c|c|}
\hline State & $\mathbf{2 0 0 7}$ & $\mathbf{2 0 0 8}$ & $\mathbf{2 0 0 9}$ & $\mathbf{2 0 1 0}$ & $\mathbf{2 0 1 1}$ & $\mathbf{2 0 1 2}$ & $\mathbf{2 0 1 3}$ & $\mathbf{2 0 1 4}$ & $\mathbf{2 0 1 5}$ & Average \\
\hline \multicolumn{10}{|c|}{ Host Country } \\
\hline RO & 29.0 & 27.6 & 26.3 & 26.2 & 28.1 & 27.7 & 27.3 & 27.5 & 28.0 & 27.5 \\
\hline LV & 28.2 & 27.8 & 27.3 & 27.9 & 27.9 & 28.6 & 28.6 & 29.0 & 29.2 & 28.3 \\
\hline LT & 30.0 & 30.6 & 30.2 & 28.3 & 27.2 & 27.0 & 27.1 & 27.6 & 29.1 & 28.6 \\
\hline IE & 30.8 & 29.0 & 28.1 & 27.9 & 27.8 & 28.3 & 28.7 & 29.1 & 23.9 & 28.2 \\
\hline CY & 36.1 & 34.8 & 31.8 & 31.9 & 31.9 & 31.6 & 31.5 & 33.2 & 33.0 & 32.9 \\
\hline BG & 31.6 & 30.7 & 27.2 & 26.0 & 25.3 & 26.7 & 28.2 & 28.4 & 29.0 & 28.1 \\
\hline \multicolumn{10}{|c|}{ Home Country } \\
\hline MT & 32.9 & 32.1 & 32.5 & 31.2 & 31.9 & 32.2 & 32.4 & 34.0 & 33.7 & 32.5 \\
\hline BE & 43.0 & 43.6 & 42.7 & 43.1 & 43.7 & 44.8 & 45.7 & 45.4 & 45.1 & 44.1 \\
\hline FR & 42.6 & 42.5 & 42.0 & 42.1 & 43.3 & 44.5 & 45.4 & 45.7 & 45.9 & 43.8 \\
\hline IT & 41.4 & 41.2 & 41.7 & 41.5 & 41.5 & 43.5 & 43.5 & 43.2 & 43.2 & 42.3 \\
\hline ES & 36.4 & 32.2 & 29.8 & 31.3 & 31.2 & 32.3 & 33.2 & 33.8 & 33.9 & 32.7 \\
\hline DE & 37.4 & 37.7 & 38.0 & 36.7 & 37.2 & 37.8 & 38.2 & 38.3 & 38.6 & 37.8 \\
\hline
\end{tabular}

Source: https://ec.europa.eu/taxation_customs/sites/taxation/files/taxation_trends

In order to study the effect of the profit shifting we included only the companies located in one of the home countries that have a related party, subsidiary, in one of the host countries. For related party, we included in the sample only those companies that are directly hold more than $51 \%$ (of the value/number of shares or voting rights) by another company. Moreover, there were included in the sample only those companies that were set up on and after 2007. 2007 is the year in which Romania and Bulgaria joined the European Union.

Information about shareholding structure / year of incorporation are found in Amadeus database. Amadeus is provided by Bureau van Dijk and contains information on more than 21 million companies located in Europe.

The companies exported from Amadeus database were manually filtered in order to: (i) mitigate the errors (i.e. companies hold by a company located in other countries than home countries); (ii) eliminate those companies that were incorporated after 2015. Further to filtering the information exported from Amadeus database 11.395 companies remained in the sample. 
Iulia Butnaru, Laura Brad, Iulian Viorel Brasoveanu

On a separate note, companies located in the home countries, Germany, Italy, Malta, Belgium, France and Spain preferred as investment location Romania (9.505 out of 11.395 subsidiaries were set up in Romania).

As a proxy for corruption we used the Corruption Perceptions Index ("CPI"). CPI was established in 1995 by Transparency International Organisation with the purpose of measuring the perceptions of corruption in the public sector.

Table 3 Evolution of the Corruption Perceptions Index, 2007 - 2015

\begin{tabular}{|l|l|l|l|l|l|l|l|l|l|l|l|l|}
\hline State & $\mathbf{2 0 0 7}$ & $\mathbf{2 0 0 8}$ & $\mathbf{2 0 0 9}$ & $\mathbf{2 0 1 0}$ & $\mathbf{2 0 1 1}$ & $\mathbf{2 0 1 2}$ & $\mathbf{2 0 1 3}$ & $\mathbf{2 0 1 4}$ & $\mathbf{2 0 1 5}$ & Average \\
\hline \multicolumn{10}{|c|}{ Host country } \\
\hline BG & 41 & 36 & 38 & 36 & 41 & 41 & 43 & 41 & 41 & 51 \\
\hline CY & 53 & 64 & 66 & 63 & 66 & 63 & 63 & 61 & 61 & 69 \\
\hline IE & 75 & 77 & 80 & 80 & 69 & 72 & 74 & 75 & 75 & 63 \\
\hline LV & 48 & 50 & 45 & 43 & 49 & 53 & 55 & 55 & 55 & 52 \\
\hline LT & 48 & 46 & 49 & 50 & 54 & 57 & 58 & 61 & 61 & 48 \\
\hline RO & 37 & 38 & 38 & 37 & 44 & 43 & 43 & 46 & 46 & 41 \\
\hline \multicolumn{10}{|c|}{ Home Country } \\
\hline BE & 71 & 73 & 71 & 71 & 75 & 75 & 75 & 76 & 77 & 72 \\
\hline FR & 73 & 69 & 69 & 68 & 70 & 71 & 71 & 69 & 70 & 75 \\
\hline DE & 78 & 79 & 80 & 79 & 80 & 79 & 78 & 79 & 81 & 61 \\
\hline IT & 52 & 48 & 43 & 39 & 39 & 42 & 43 & 43 & 44 & 50 \\
\hline MT & 58 & 58 & 52 & 56 & 56 & 57 & 56 & 55 & 56 & 59 \\
\hline ES & 67 & 65 & 61 & 61 & 62 & 65 & 59 & 60 & 58 & 62 \\
\hline
\end{tabular}

Source: authors' computation with data exported from http://www.transparency.org/ Note: If the CPI is closed to 0 it means that the respective country is highly corrupted, otherwise if the CPI is closed to 100 it means that the respective country is clean.

As can be observed in Table 3, both home and host countries are dealing with corruption. However, Romania records the highest level of perceived corruption (average CPI 41), while France is the country with the lowest level of perceived corruption.

Another proxy for corruption used is EFW index. EFW index measures the degree of economic freedom present in five major areas: size of government; legal system and security of property rights; sound money; freedom to trade internationally; regulation. A high value of the index indicates that the legal system protects the property rights, the corruption is not tolerated, the government is not corrupted and the international trade is promoted, poverty eliminated. 
Profit Shifting of European Multinational Companies and Corruption

Table 4: Evolution of the EFW index during the period 2007 - 2015

\begin{tabular}{|l|c|c|c|c|c|c|c|c|c|c|}
\hline State & $\mathbf{2 0 0 7}$ & $\mathbf{2 0 0 8}$ & $\mathbf{2 0 0 9}$ & $\mathbf{2 0 1 0}$ & $\mathbf{2 0 1 1}$ & $\mathbf{2 0 1 2}$ & $\mathbf{2 0 1 3}$ & $\mathbf{2 0 1 4}$ & $\mathbf{2 0 1 5}$ & Average \\
\hline \multicolumn{10}{|c|}{ Host country } \\
\hline BG & 62.7 & 63.7 & 64.6 & 62.3 & 64.9 & 64.7 & 65 & 65.7 & 66.8 & 64.49 \\
\hline CY & 71.7 & 71.3 & 70.8 & 70.9 & 73.3 & 71.8 & 69 & 67.6 & 67.9 & 70.48 \\
\hline IE & 82.6 & 82.5 & 82.2 & 81.3 & 78.7 & 76.9 & 75.7 & 76.2 & 76.6 & 79.19 \\
\hline LV & 67.9 & 68.3 & 66.6 & 66.2 & 65.8 & 65.2 & 66.5 & 68.7 & 69.7 & 67.21 \\
\hline LT & 71.5 & 70.9 & 70 & 70.3 & 71.3 & 71.5 & 72.1 & 73 & 74.7 & 71.70 \\
\hline RO & 61.2 & 61.7 & 63.2 & 64.2 & 64.7 & 64.4 & 65.1 & 65.5 & 66.6 & 64.07 \\
\hline \multicolumn{10}{|c|}{ Home Country } \\
\hline BE & 72.5 & 71.7 & 72.1 & 70.1 & 70.2 & 69 & 69.2 & 69.9 & 68.8 & 70.39 \\
\hline FR & 62.1 & 64.7 & 63.3 & 64.2 & 64.6 & 63.2 & 64.1 & 63.5 & 62.5 & 63.58 \\
\hline DE & 70.8 & 70.6 & 70.5 & 71.1 & 71.8 & 71 & 72.8 & 73.4 & 73.8 & 71.76 \\
\hline IT & 62.8 & 62.6 & 61.4 & 62.7 & 60.3 & 58.8 & 60.6 & 60.9 & 61.7 & 61.31 \\
\hline MT & 66.1 & 66 & 66.1 & 67.2 & 65.7 & 67 & 67.5 & 66.4 & 66.5 & 66.50 \\
\hline ES & 69.2 & 69.1 & 70.1 & 69.6 & 70.2 & 69.1 & 68 & 67.2 & 67.6 & 68.90 \\
\hline
\end{tabular}

Source: Authors' computation with data exported from

https://www.heritage.org/index/Note: If the EFW index is closed to 100 it means that the respective country enjoys the economic freedom.

Countries that record an average EFW index between 70 and 79.9, in our specific case Belgium, Cyprus, Lithuania and Ireland are considered as being mostly free, while an average EFW index between 60 and 69.9 indicates a moderately economic freedom for the rest of the analysed countries

As the host countries are the countries with the lowest CIT rate, we considered that we could do a split among them based on their statutory tax rate. We constructed a dummy variable, named High Tax (HT), that takes value 1 if the statutory tax rate is higher than 15 (or more precisely is above the average) and 0 otherwise. The idea is to reveal than when you have to choose between countries with low taxation, smaller differences between statutory corporate income tax rates doesn't have a significant impact, rather the level of corruption or the cost of labour force influence the investment decision.

\section{Results and discussions}

In order to observe if the investment is significantly affected by the level of taxation or by other variables, such as the level of corruption, the level of economic freedom or the cost of the labour force, several models were conducted. The influence was also measured considering the level of statutory tax rate (highest tax rate from the lowest ones) that the host country has, the fiscal pressure or the 
Iulia Butnaru, Laura Brad, Iulian Viorel Brasoveanu

effective average tax rate that was registered in the host country. In Table 5 the descriptive statistics of the analysed variables is presented.

Table 5. Descriptive statistics of the variables included into analysis

\begin{tabular}{|c|c|c|c|c|c|c|c|c|}
\hline El. & $\begin{array}{c}\text { No } \\
\text { subs }\end{array}$ & $\begin{array}{c}\text { No subs. } \\
\text { /thous.Cap }\end{array}$ & $\begin{array}{c}\text { CPI } \\
\text { host }\end{array}$ & $\begin{array}{c}\text { EFW } \\
\text { Host }\end{array}$ & $\begin{array}{c}\text { LB } \\
\text { cost }\end{array}$ & $\begin{array}{c}\text { Statutory } \\
\text { tax rate } \\
\text { host }\end{array}$ & $\begin{array}{c}\text { EATR } \\
\text { host }\end{array}$ & $\begin{array}{c}\text { FP } \\
\text { host }\end{array}$ \\
\hline Mean & 35.17 & 44.30 & 53.78 & 69.52 & 1.27 & 13.31 & 12.87 & 28.92 \\
\hline Median & 5.00 & 12.88 & 51.50 & 68.50 & 1.39 & 13.75 & 13.70 & 28.27 \\
\hline Max. & 787.00 & 690.07 & 80.00 & 82.60 & 1.67 & 20.00 & 16.80 & 36.07 \\
\hline Min. & 0.00 & 0.00 & 36.00 & 61.20 & 0.15 & 10.00 & 8.80 & 23.88 \\
\hline Skew. & 102.36 & 89.60 & 12.83 & 5.47 & 0.32 & 2.48 & 2.19 & 2.29 \\
\hline Kurt. & 4.81 & 4.10 & 0.46 & 0.79 & -1.18 & 0.00 & -0.70 & 0.88 \\
\hline
\end{tabular}

Source: authors' computation

From Table 5 we can observe that the number of subsidiaries per thousand capita is higher than the number of subsidiaries found in the host countries. Regarding the index of corruption this is between 36 and 80, while the index of economic freedom is between 61.20 and 82.60 . The fiscal pressure is between 23.88 and 36.07. Neither variable has a normal distribution. Table 6 reveals the results when the influence of corruption is measured on the number of subsidiaries.

Table 6 The impact of index of corruption on the number of subsidiaries

\begin{tabular}{|l|l|l|l|l|}
\hline \multicolumn{5}{|l|}{ Dependent variable: Number of subsidies } \\
\hline Variables & Model 1 & Model 2 & Model 3 & Model 4 \\
\hline Constant & $65.2204^{* * *}$ & $68.6866^{* * *}$ & $25.9597 * * *$ & $39.4760^{* * *}$ \\
\hline CPI & $-0.5587^{* * *}$ & $-0.7279^{* * *}$ & & \\
\hline CPI x HT & & $0.2323^{*}$ & & \\
\hline LB & & & $-.410(\mathrm{p}=0.90)$ & \\
\hline LB x HT & & & $13.9062^{* * *}$ & \\
\hline LB x CPI & & & & $-0.1627 * *$ \\
\hline LB x CPI x HT & & & & $0.1889^{* *}$ \\
\hline R squared & $12.18 \%$ & $13.69 \%$ & $8.63 \%$ & $6.28 \%$ \\
\hline Adj. R squared & $9.66 \%$ & $10.93 \%$ & $5.71 \%$ & $3.29 \%$ \\
\hline F statistic & 4.8405 & $4.9653^{* * *}$ & $2.9571^{* * *}$ & $2.1008 * *$ \\
\hline DW & 1.98 & 1.99 & 2.05 & 2.16 \\
\hline $\begin{array}{l}\text { Redundant. } \\
\text { fixed effect }\end{array}$ & No $(\mathrm{p}=0.0021)$ & No $(\mathrm{p}=0.0037)$ & No $(\mathrm{p}=0.0082)$, & No $(\mathrm{p}=0.0585)$, \\
\hline
\end{tabular}

Source: authors' computation, where $* * *$ and $* *$ denotes significant level at $1 \%$ and 5 
Profit Shifting of European Multinational Companies and Corruption

Based on Table 6, we observed that higher the corruption is in the host country, the number of subsidiaries is increasing in the host country. The explanation is due to the fact that the index of corruption reveals higher corruption when it has smaller values. The results found in Table 6 emphasize that there is an indirect correlation between the index of corruption and the number of subsidiaries. As a fact, as the index of corruption is increasing (less corruption), the number of subsidiaries is decreasing and vice-versa. The results are similar with the one found by Habu and Siedel (version 2017). Moreover, the results reveal that the level of corruption is more important than the level of taxation. We tested if the marginal effect of corruption is also affected by the host statutory tax rate (highest values from the minimum ones). In other words, we tested if an increase in the host statutory corporate income tax is related with higher number of subsidiaries in countries where the corruption is high. The results emphasize that even if the investment is done in a country with a high corporate income tax rate (the highest of the lowest corporate income tax rates), when is combined with higher corruption, the number of subsidiaries is still increasing.

Regarding the labour force, results reveal that the investment is preferred in countries with low labour cost, even though the coefficient is not statistically significant. On the other hand, we can observe that the investment is preferred in the host country where the cost of labour is smaller even though it has the highest of the lowest statutory/corporate income tax rates. The combination between the index of corruption and the labour force is also significant. The results present the fact that lower the value of their product is, higher the number of subsidiaries is. This suggests that the number of subsidiaries is significantly influenced by the cost of labour (lower cost) and by the level of corruption (higher). The investment decision is maintained even if the level of corporate income/statutory tax rate is taken into account. The models are statistically significant; the autocorrelation and heteroscedasticiy are adjusted though the way the estimation was conducted. If we take into account the fixed effect, we can observed that between 2007-2010 less investment is done, while between 2011-2014 more subsidiaries were set up. considered.

Table 7 presents the results found when the index of economic freedom is

Table 7 the impact of index of economic freedom on the number of subsidiaries

\begin{tabular}{|l|l|l|l|}
\hline \multicolumn{4}{|l|}{ Dependent variable: number of subsidiaries } \\
\hline Variables & Model 1 & Model 2 & Model 3 \\
\hline Constant & $178.4389 * * *$ & 108.1532 & $30.2345^{* * *}$ \\
\hline EFW & $-2.0607 * * *$ & $-1.4727 * * *$ & \\
\hline EFW x HT & & $0.2064(\mathrm{p}=0.1458)$ & \\
\hline
\end{tabular}


Iulia Butnaru, Laura Brad, Iulian Viorel Brasoveanu

\begin{tabular}{|l|l|l|l|}
\hline \multicolumn{4}{|l|}{ Dependent variable: number of subsidiaries } \\
\hline Variables & Model 1 & Model 2 & Model 3 \\
\hline LB x EFW & & & $\begin{array}{l}-0.0288 \\
(\mathrm{p}=0.5537)\end{array}$ \\
\hline LB x EFW x HT & & & $0.1576^{* * *}$ \\
\hline R squared R & $9.79 \%$ & $7.75 \%$ & $9.55 \%$ \\
\hline $\begin{array}{l}\text { Adjusted } \\
\text { squared }\end{array}$ & $4.20 \%$ & $6.60 \%$ \\
\hline F statistic & $3.7873^{* * *}$ & $2.6298^{* * *}$ & $3.3058^{* * *}$ \\
\hline DW & 2.0145 & 2.08 & 2.05 \\
\hline $\begin{array}{l}\text { Redundant fixed } \\
\text { effect }\end{array}$ & No $(\mathrm{p}=0.0628)$ & $\begin{array}{l}\text { Yes ( p=0.1890) } \\
\text { no effect chosen }\end{array}$ & No $(\mathrm{p}=0.0014)$ \\
\hline
\end{tabular}

Source: authors' computation, where *** denotes significant level at 1\%

From Table 7, it can be seen that there is an indirect correlation between the economic freedom index and the number of subsidiaries. As a fact, smaller the index of economic freedom is, higher the number of subsidiaries is. That means that the investment is preferred in countries where the legal system doesn't protects the property rights, the corruption is tolerated, the government is corrupted and the poverty is high. As it can be seen, from Table 7, the number of subsidiaries is increasing event though there is a high statutory/corporate income tax rate. That means the marginal effect of economic freedom is also affected by the level of statutory/corporate tax rate (the highest from the minimum host statutory tax rates). In other words, we tested if an increase in the host statutory tax/corporate income tax rate is related with higher number of subsidiaries in countries where the economic freedom is low. The results emphasize that even if the investment is done in a country with a high statutory tax rate (the highest of the lowest statutory tax rates), when is combined with lower economic freedom, the number of subsidiaries is still increasing. If we consider that the economic freedom could also be a proxy for corruption than the results are similar with the one found by Habu and Siedel (version 2017).

The results reveal that the number of subsidiaries is increasing if there is a small value of the product between the index of economic freedom and the labour cost. Smaller values are obtained when the labour cost is low or the index of economic freedom has lower values or both. Regarding the creditworthiness of the model, the first model could be estimated both with Period fixed effect or without them as the probability of rejecting the null hypothesis (there is no significance difference between fixed effects) is 0.1890 . We are in the uncertainty area. If we assume a risk of $18.90 \%$ of rejecting the null hypothesis then the period fixed effect is relevant. The models are statistically significant; the autocorrelation and heteroscedasticity are adjusted though the way the estimation is conducted. If we 
Profit Shifting of European Multinational Companies and Corruption

take into account the fixed effect, we can observe that 2008-2010 was the worst period, while between 2011-2014 more investments were done.

We also wondered if the taxation statutory /corporate income tax rate, the effective average tax rate or the fiscal pressure found in the host country affects significantly the decision of investment. The results are presented in Table 8 .

Table 8 The impact of fiscal variables on the number of subsidiaries

\begin{tabular}{|l|l|l|l|}
\hline Dependent variable: number of subsidiaries \\
\hline Variables & Model 1 & Model 2 & Model 3 \\
\hline Constant & $41.7366^{* * *}$ & $5.6792(\mathrm{p}=0.5132)$ & $-39.6393^{* * *}$ \\
\hline FP & $-1.2494^{* * *}$ & & \\
\hline EATR & & $2.2906^{* * *}$ & \\
\hline CIT_host & & & $5.6184^{* * *}$ \\
\hline R squared & $2.13 \%$ & $6.69 \%$ & $14.42 \%$ \\
\hline $\begin{array}{l}\text { Adjusted } \\
\text { squared }\end{array}$ & $1.83 \%$ & $4.02 \%$ & $11.97 \%$ \\
\hline F statistic & $7.0393 * * *$ & $2.5047^{* * *}$ & $5.8817 * * *$ \\
\hline DW & 2.05 & 1.80 & 1.82 \\
\hline $\begin{array}{l}\text { Redundant fixed } \\
\text { effect }\end{array}$ & No $(0.0202)$ & No $(\mathrm{p}=0.0238)$ & No $(\mathrm{p}=0.0023)$ \\
\hline
\end{tabular}

Source: authors' computation, where *** denotes significant level at $1 \%$

The results found in Table 8 are a little bit ambiguous. On one hand, it seems that the number of subsidiaries is increasing simultaneously with the increase of EATR or of statutory/corporate income tax rate; on the other hand, the number of subsidiaries is decreasing when the fiscal pressure is increasing. In our opinion, it is more important the overall fiscal pressure result, rather than individual taxes, as it incorporates both the obligations that the employers have to cover for their employees, together with other fiscal obligations. The results regarding EATR and the statutory/corporate income tax rate could be due to the fact that the selected countries have the lowest statutory tax rates from Europe.

In order to reveal the robustness of our analysis, we decide to retest it by considering the dependent variable as the number of subsidiaries per thousand capita. The data about population was taken from Eurostat. The results regarding the influence of the index of corruption are presented in Table 9. 
Iulia Butnaru, Laura Brad, Iulian Viorel Brasoveanu

Table 9 The impact of index of corruption on the number of subsidiaries- the robustness analysis

\begin{tabular}{|c|c|c|c|c|}
\hline \multicolumn{5}{|c|}{ Dependent variable: the number of subsidiaries per thousand capita } \\
\hline Variables & Model 1 & Model 2 & Model 3 & Model 4 \\
\hline Constant & $66.1024 * * *$ & $51.5931 * * *$ & $44.0540 * * *$ & $51.1515^{* * *}$ \\
\hline CPI & $-0.4054 * *$ & $\begin{array}{l}-0.2001 \\
(p=0.2291)\end{array}$ & & \\
\hline CPI x HT & & $\begin{array}{l}0.1430 \\
(p=0.2326)\end{array}$ & & \\
\hline $\mathbf{L B}$ & & & $\begin{array}{l}-7.5202 \\
(p=0.4535)\end{array}$ & \\
\hline LB x HT & & & $14.0098 * * *$ & \\
\hline LB x CPI & & & & $\begin{array}{l}-0.2047 \\
(p=0.1433)\end{array}$ \\
\hline $\begin{array}{lll}\text { LB } & \text { x } & \text { CPIx } \\
\text { HT } & & \\
\end{array}$ & & & & $0.1953 * *$ \\
\hline R squared & $13.30 \%$ & $10.23 \%$ & $10.45 \%$ & $9.88 \%$ \\
\hline $\begin{array}{ll}\begin{array}{l}\text { Adjusted } \\
\text { squared }\end{array} & \text { R }\end{array}$ & $10.82 \%$ & $7.36 \%$ & $7.58 \%$ & $7.01 \%$ \\
\hline F statistic & $5.3552 * * *$ & $3.5682 * * *$ & $3.6527 * * *$ & $3.4349 * * *$ \\
\hline DW & 1.96 & 1.99 & 2.02 & 2.02 \\
\hline $\begin{array}{l}\text { Redundant } \\
\text { fixed effect }\end{array}$ & $\begin{array}{l}\text { No } \\
(\mathrm{p}=0.0000)\end{array}$ & $\begin{array}{l}\text { No } \\
(p=0.0001)\end{array}$ & $\begin{array}{l}\text { No } \\
(\mathrm{p}=0.0003),\end{array}$ & $\begin{array}{l}\text { No } \\
(\mathrm{p}=0.0006)\end{array}$ \\
\hline
\end{tabular}

Source: authors' computation, where ${ }^{* * *}$ and ${ }^{* *}$ denotes significant level at $1 \%$ and $5 \%$

As it can be seen from Table 9, the results are identical in terms of the influence of the independent variables. Significant differences appear in terms of statistical significance of the coefficient. As a fact, in model 2, even though the coefficient of corruption is not statistically significant, together with the product between the index of corruption and the high tax rate (the dummy variable), the model seems statistically significant. Other differences appear in model 4 when the cumulative effect between the labour cost and corruption is encountered. However, we emphasize that the signs of the coefficients are identical with the ones found in Table 6, which means that the influence persists. We consider that rather than the econometrical interpretation, the economic one is more important. As a fact, higher the corruption is, larger the number of subsidiaries per thousand capita is. If we assume a risk of $23.26 \%$ of rejecting the null hypothesis (that the value of the coefficient is not statistically significant from zero) than the results and the interpretation is similar with the one found in Table 6. The cost of labour force should be negatively correlated with the number of subsidiaries per thousand 
Profit Shifting of European Multinational Companies and Corruption

capita, the investment is directed to countries where both the index of corruption is low (high corruption is found) and the labour cost is smaller, while the statutory has rate /corporate income tax rate (the highest statutory/corporate income tax rate from the minimum ones- represented by the dummy variable) is still affecting the marginal effect of independent variables, increasing the number of subsidiaries per thousand capita.

Table 10 emphasizes the results regarding the index of economic freedom when the robustness analysis is conducted.

Table 10. The impact of index of economic freedom on the number of subsidiaries robustness analysis

Dependent variable: the number of subsidiaries per thousand capita

\begin{tabular}{|l|l|l|l|}
\hline Variables & Model 1 & Model 2 & Model 3 \\
\hline Constant & $147.9795^{* * *}$ & $125.0153^{* * *}$ & $50.2610^{* * *}$ \\
\hline EFI & $-1.4912^{* *}$ & $-1.2075^{* *}$ & \\
\hline EFI x HT & & $0.0955(\mathrm{p}=0.3191)$ & \\
\hline LB x EFI & & & $-0.1642(\mathrm{p}=0.2502)$ \\
\hline LB x EFIx HT & & & $0.1772^{* * *}$ \\
\hline R squared & $9.30 \%$ & $9.28 \%$ & $10.23 \%$ \\
\hline $\begin{array}{l}\text { Adjusted } \\
\text { squared }\end{array}$ & $6.70 \%$ & $6.38 \%$ & $7.36 \%$ \\
\hline F statistic & $3.5778^{* * *}$ & $3.2018^{* * *}$ & $3.5681^{* * *}$ \\
\hline DW & 1.97 & 1.98 & 2.02 \\
\hline $\begin{array}{l}\text { Redundant fixed } \\
\text { effect }\end{array}$ & No $(\mathrm{p}=0.00618)$ & No $(\mathrm{p}=0.0034)$ & No $(\mathrm{p}=0.0004)$ \\
\hline
\end{tabular}

Source: authors' computation, where $* * *$ denotes significant level at $1 \%$

From Table 10, it can be observed that there is an indirect correlation between the index of economic freedom and the number of subsidiaries per thousand capita. That means that when the economic freedom is high (low corruption), the number of subsidiaries per thousand capita is decreasing, while when the index of economic freedom is low (that is correlated with high corruption level), the number of subsidiaries per thousand capita is increasing. Regarding the influence of the other variables included into the analysis, we distinguish the same differences found in Table 6 and Table 9. The problem that appears is related with the significance of some coefficient. That means that we should accept higher risk to reject the null hypothesis (for example $25.02 \%$ ). The idea is that we are in the uncertainly area. On the other hand, if we look only at the sign of the coefficient than we can conclude that the investment is done in countries where the labour force cost is small or where the index of the economic freedom is small. Regarding 
Iulia Butnaru, Laura Brad, Iulian Viorel Brasoveanu

the marginal effect of the index of economic freedom, it is also affected by the host statutory/corporate income tax rate (highest values from the minimum ones). The results regarding the number of subsidiaries per thousand capita are similar with the one found when the dependent variable is the number of subsidiaries.

Table 11 presents the results regarding the taxation variables when the robustness analysis is conducted.

Table 11 The impact of fiscal variables on the number of subsidiariesrobustness analysis

\begin{tabular}{|c|c|c|c|}
\hline \multicolumn{4}{|c|}{ Dependent variable: the number of subsidiaries per thousand capita } \\
\hline Variables & Model 1 & Model 2 & Model 3 \\
\hline Constant & $\begin{array}{l}31.0703 \\
(\mathrm{p}=0.1760)\end{array}$ & $23.2511 * *$ & $\begin{array}{l}-8.2179 \\
(\mathrm{p}=0.5568)\end{array}$ \\
\hline FP & $0.4574(\mathrm{p}=0.5659)$ & & \\
\hline EATR & & $1.6349 * *$ & \\
\hline CIT & & & $3.9442 * * *$ \\
\hline R squared & $8.17 \%$ & $9.34 \%$ & $14.15 \%$ \\
\hline $\begin{array}{ll}\text { Adjusted } & \text { R } \\
\text { squared } & \end{array}$ & $5.54 \%$ & $6.74 \%$ & $11.69 \%$ \\
\hline F statistic & $3.1062 * * *$ & $3.5958 * * *$ & $5.7513 * * *$ \\
\hline DW & 2.01 & 1.98 & 2.02 \\
\hline $\begin{array}{l}\text { Redundant fixed } \\
\text { effect }\end{array}$ & $\begin{array}{l}\text { No }(0.0011) \text { period } \\
\text { fixed effect chosen }\end{array}$ & $\begin{array}{l}\text { No } \quad(p=0.0003) \\
\text { period fixed effect } \\
\text { chosen }\end{array}$ & $\begin{array}{l}\text { No } \quad(p=0.0000) \\
\text { period fixed effect } \\
\text { chosen }\end{array}$ \\
\hline
\end{tabular}

Source: authors' computation, where $* * *$ and $* *$ denotes significant level at $1 \%$ and at $5 \%$

From Table 11 it can be concluded that the fiscal pressure do not affect the number of subsidiaries per thousand capita as its coefficient has a probability of $56.59 \%$ of rejecting the null hypothesis that the value of the coefficient is statistically different from zero. On the other side, the sign of the coefficient is opposed to the sign found in Table 8. When the statutory/corporate income tax rate or the EATR rate is analyzed, we conclude that the influence is similar with the one found on Table 8. That means that the number of subsidiaries per thousand people increases as those taxes increases. The explanation could be due to the fact that the selected countries have the lowest statutory/corporate income tax rates from Europe and the investment was more focused in countries that have the highest from the minimum tax rates. 
Profit Shifting of European Multinational Companies and Corruption

\section{Conclusions}

The present research tries to emphasize the influence of corruption on profit shifting of multinational companies. The analysis was conducted on 36 home-host countries characterized by high and low taxation rates. The idea of research is to reveal that not only the taxation is important, rather other factors, such as the corruption, the economic freedom or the costs of labour force are significant when the decision of creating additional subsidiaries is taken. The analysis uses the Panel data analysis on 9 years, from 2007-2015. The data was estimated using Eviews 9.0. The method of estimation was Period SUR effect within the generalized least square method associated with White period within the correlation matrix using period fixed effects. It corrects for heteroscedasticity and general correlation of observations within a cross-section and it reflects the influence of investment based on the analyzed period. Overall, it could be said that more subsidiaries were set up between 2011-2014 while the period of small investment (small number of subsidiaries) was between 2008-2010.

In order to choose the home-host countries, data from Amadeus were selected. Related party were considered only those companies that are directly held more than $51 \%$ by the home countries. The home countries were the countries that have the highest statutory CIT rate: Belgium, Spain, Germany, Italy, France and Malta, while the host countries were Cyprus, Bulgaria, Romania, Lithuania, Latvia and Ireland. The dependent variable was the number of subsidiaries that were set in the host countries. The results were also checked considering the robustness of the analysis that was conducted. In this stage of the analysis, the dependent variable was the number of subsidiaries per thousand capita.

The results emphasize that there is an indirect correlation between both the index of corruption and the dependent variable and the index of economic freedom and the number of subsidiaries or the number of subsidiaries per thousand capita. That means that they are increasing when corruption is high or when the economic freedom is low, element that allows the existence of high corruption. Moreover, the investment is preferred in host countries that have the lowest cost of labour force. It has to be mention that the decision of investment is not significantly influence by the statutory CIT tax rate. In other words, the marginal effect of corruption, of economic freedom or of labour cost is also affected by the CIT statutory tax rate (the highest from the minimum). It could be said that when there are smaller differences regarding the CIT tax rate, other elements such as the corruption (high), the cost of the labour force (small) and the economic freedom (less) affects significantly the decision of investment.

When it comes to taxation, it seems that EATR host rate or the CIT host rate affects the number of subsidiaries or the number of subsidiaries per thousand capita. The explanation could be due to the fact that the selected countries have the lowest tax rates from Europe and the investment was more focused in countries 
Iulia Butnaru, Laura Brad, Iulian Viorel Brasoveanu

that have the highest from the minimum tax rates as the corruption is in general higher here. The fiscal pressure influences the number of subsidiaries negatively, but is not significant when the number of subsidiaries per thousand capita is taken into account.

The value added of the study consists firstly in analysing the influence of corruption and of economic freedom on the number of subsidiaries or on the number of subsidiaries per thousand capita. Previous studies (Heckemeyer and Overesch-2013, Lohse and Riedel -2013, De Mooij and Ederveen (2008, Crivelli, E, De MooijR.and Keen, M. (2015) took the effect on financial indicators such as EBITDA, EBIT and so on. Only the study of HabuandSiedel (version 2017) proposed a theoretical model though which they analyze the impact of corruption on profit shifting. Our results are similar in terms of the effect that the corruption has, as the corruption increases profit shifting that a multinational company performs and it amplifies the incentives of the profit shifting activity. They also concluded that higher the corporate income tax on the home country is, larger the effect of corruption when profit shifting activities are considered. Their theoretical model is in concordance with our results.

Secondly, our model creates value added by the fact that the results were also checked with robustness analysis. The idea was to reveal if the influence of the index of corruption or of the index of economic freedom persists when the dependent variable is the number of subsidiaries per thousand capita. Mainly, we wanted to check if the results are similar in the case when the dependent variable is comparable among countries. The models conducted reveal both that as the corruption and the economic freedom decreases the number of subsidiaries per thousand capita increases. Thus, it is confirm that higher the corruption is, higher the profit shifting activities are.

Thirdly, our analysis differs from other in terms of methodology used as the results were corrected for heteroscedasticity and autocorrelation. Besides other results, our analysis corrects the correlation within cross countries and surprises the differences between several periods of time.

\section{Further work}

A fascinating future research project is to observe the impact of the corruption, economic freedom, CIT rate, EATR, fiscal pressure on the number of subsidiaries that activate in a certain industry (i.e. manufacturing, agriculture, construction, real estate etc.). A factor that is significant for the companies that activate in a certain industry may be irrelevant for the companies that activate in a different industry.

For the future, we intend to include in the sample more countries in order to increase the data sample, and consequently, the level of statistical significance of the models. 
Profit Shifting of European Multinational Companies and Corruption

Furthermore, it is interesting to observe if investors decide to direct their funds in countries located closer to their home country or the distance does not represent any longer an impediment to invest in a certain country.

Potential future research project in this area may involve the identification of other factors that may influence the foreign investment decision. For example is interesting to observe how variables related to population structure (i.e. age, sex), education (i.e. graduates by education level, average number of foreign languages studied), labour market (i.e. unemployment, job vacancy), environment (i.e. environment taxes), finance (i.e. interest rate level) etc. may influence the business decision of the multinational companies.

Furthermore the authors intend to study the behaviour of multinational companies in different periods: before crisis, during a crisis and after crisis and aim to include the effect or region, geography or country.

\section{REFERENCES}

[1] Buckley J.P. and Pervez N. G. (2015),International Business Strategy: Theory and Practice, edited by Routledge: 10-21;

[2]Buettner T. and Ruf M. (2007),Tax Incentives and the Location of FDI: Evidence from a Panel of German Multinationals; International Tax and Public Finance, 14(2): 151-164;

[3]Crivelli, E, De Mooij R. and Keen, M. (2015),Base Erosion, Profit Shifting and Developing Countries. IMF Working Paper, WP/15/118;

[4[De Mooij, R. A., Ederveen, S. (2008), Corporate Tax Elasticities: A Reader's Guide to Empirical Findings; Oxford Review on Economic Policy, 24(4) : $680-697$

[5]European Commission (2011 / 2016),Common Consolidated Corporate Tax Base ("CCCTB") proposed directive; available online https://ec.europa.eu/taxation_customs/business/company-tax/commonconsolidated-corporate-tax-base-ccctb_en, last accessed 25.03.2017;

[6]Fuest C., Spengel C., Finke K., Heckemeyer J. H. and Nusser H. (2013), Profit Shifting and "Aggressive" Tax Planning by Multinational Firms: Issues and Options for Reform; Center for European Research, Discussion Paper No. 13044;

[7]Grubert H. and Mutti J. (1991), Taxes, Tariffs and Transfer Pricing in Multinational Corporate Decision Making. The Review of Economics and Statistics, 73(2): 285-93; 
Iulia Butnaru, Laura Brad, Iulian Viorel Brasoveanu

[8]Habu, K., Siedel, A. (2017 version).Profit Shifting and Corruption. Available online at

https://katarzynahabu.weebly.com/uploads/1/0/3/5/103570280/profit_shifting_and _corruption.pdf, last accessed 25.03.2017;

[9]Heckemeyer, J. H. and Overesch, M. (2013), Multinational's Profit Response to Tax Differentials: Effect Size and Shifting Channels. ZEW Discussion Paper, No. 13-045: 1-32;

[10]Hines J.R. (1999), Leasons from Behavioural Responses to International Taxation; National Tax Journal 52:305-322;

[11]Huizinga H. and Laeven Luc (2006), International Profit Shifting within Multinationals: A Multi-Country Perspective; Econ Papers, N 260:1-47;

[12]Lohse, Tand Riedel, N. (2013), Do Transfer Pricing Laws Limit

International Income Shifting? Evidence from European Multinationals.

CESifo Working Paper No. 4404 (2013): 1-30;

[13]Newlon S. (2000),Transfer Pricing and Income Shifting in Integrating

Economies, Taxing Capital Income in the European Union: Issues and Options for Reform; Oxford Univ. Press, ISBN 0198297831: 214-242;

[14]OECD, (2013)Action Plan on Base Erosion and Profit Shifting, pp. 1-44;

[15]Vermaat, M., Sebok, S., Freund, S., Campbell, J. and Frydenberg, M.

(2014), Discovering Computers. Boston: Cengage Learning: 446-448;

[16]Wooldridge, J. M. (2002), Econometric Analysis of Cross Section and Panel

Data. The Mit Press, London, England. 